\title{
Spectral Properties Observations: a First Comparison of Bulgarian and Chilean Mountain Lakes
}

\author{
Patricio De los Ríos Escalante ${ }^{1,2 *}$, Patricio Acevedo ${ }^{3,4}$, Ivan Pandourski ${ }^{5}$ \\ ${ }^{1}$ Laboratorio de Ecología Aplicada y Biodiversidad, Escuela de Ciencias Ambientales, Facultad de Recursos Naturales, \\ Universidad Católica de Temuco, Casilla15-D, Temuco, Chile \\ ${ }^{2}$ Núcleo de Estudios Ambientales, UC Temuco \\ ${ }^{3}$ Departamento de Ciencias Físicas, Facultad de Ingeniería y Ciencias, Universidad de LaFrontera, Casilla 54-D, Temuco \\ ${ }^{4}$ Center for Optics and Photonics, Universidad de Concepción, Casilla4012, Concepción, Chile \\ ${ }^{5}$ Institute of Biodiversity and Ecosystem Research, Bulgarian Academy of Sciences, Sofia, Bulgaria
}

Received: 14 February 2016

Accepted: 14 April 2016

\begin{abstract}
While Bulgaria has oligotrophic lakes in mountain zones with Pinus mugus shrubs associated with mountains with Fagus forests, northern Chilean Patagonia has numerous pristine lakes associated with Nothofagus forests. The present study consists of an optical properties description of mountain lakes from Bulgaria with Chilean mountain lakes (Huerquehue and Alerce Andino National Parks) with Nothofagus forest, in visible, close, and medium infrared wavelengths. The results revealed that Bulgarian lakes have different optical properties than Chilean lakes, in spite of the oligotrophy associated with surrounding vegetation and geological characteristics of both groups of studied sites.
\end{abstract}

Keywords: remote sensing, satellite images, lakes, oligotrophy

\section{Introduction}

The Rila mountains in Bulgaria have lakes located at $42^{\circ} \mathrm{N}$. Their surrounding vegetation is characterized by Pinus mugus shrubs, above which lie the native coniferous and Fagus L. forest [1-2]. In contrast, Chilean north Patagonian lakes are located between $39-41^{\circ} \mathrm{S}$, with Nothofagus forest as dominant genus [3-5]. Both groups of lakes are pristine, located in protected zones that are difficult to access due the surrounding mountains and forests [1-4]. In this scenario we first conducted a comparative study about zooplankton assemblages in both kinds of lakes, and in spite of the oligotrophy we found marked differences [4].

On the basis of studies using remote sensing techniques done for Chilean Patagonian lakes that are characterized by their access difficulties [5-7], it would be possible to do a comparative study of both groups of mountain lakes. The aim of the present study is to compare spectral properties data obtained on LANDSAT ETM+ in Bulgarian Rila mountains with lakes of Alerce Andino and Huerquehue National Parks typical of northern Patagonian mountain lakes, considering the geographical and ecological differences between the two regions [4].

*e-mail:prios@uct.cl 


\section{Material and Methods}

Studied sites: Bulgarian Rila mountain lakes are oligotrophic in high altitude zones with Pinus mugus shrubs above the native coniferous and Fagus L. forest [1-2]. Their origin is volcanic and glacial at high altitudes, and low human intervention [1-2].

Huerquehue National Park $\left(39^{\circ} \mathrm{S}\right.$, Chile) lakes (Toro, Triangulo, Verde, and Tinquilco) are oligotrophic with glacial origin. These are associated with native Nothofagus Blume forest, particularly N. antarctica (G. Forst.) Oerst., $N$. pumilio (Poepp. et Endl.) Krasser, and N. dombeyi (Mirb.) Oerst. At altitudes greater than 1,000 m a.s.1., these species coexist with Araucaria araucana (Molina) K. Koch, between $38-39^{\circ} \mathrm{S}$ [3-5].

Alerce Andino National Park $\left(39^{\circ} \mathrm{S}\right.$, Chile) lakes (Chaiquenes, Sargazo, and Triangulo) are oligotrophic with glacial origin and these are associated with Nothofagus forests that coexist with Fitzroya cupressoides forest [4-5].

The remote sensing procedures in this step used a LANDSAT/ETM+ image obtained from 15 July 2012 from Rila mountain lakes [1-2] and lakes of Huerquehue and Alerce Andino National Parks, Chile, dated from 15 February $2012[1-2,4-5]$ (Table 1 ) provided by the
Land Processess Distributed Active Archive Center (LP DAAC) of the U.S. Geological Survey (http://LPDAAC. usgs.gov). The bands of visible, near, and mid-infrarred were calibrated radiometrically to spectral irradiance and then to reflectance with atmospheric correction being applied (Table 2). Reflectance was applied as principal correspondence analysis for obtaining the grouping for sampled sites. This statistical analysis was applied using Analyze-it software based on the methodology used for Patagonian lakes [6-8].

\section{Results}

The results revealed that Bulgarian lakes are different from Chilean lakes in B1, B2, and B3 reflectance (Table 1), and for Bulgarian lakes the most different in reflectance are Bliznaka, Braveka, and Dolnoto. These differences would be associated with surrounding vegetation, and the origins of both groups of studied lakes.

The correlation analysis (Pearson correlation test) revealed direct significant correlations between B1 with $\mathrm{B} 2(\mathrm{R}=0.499 ; \mathrm{p}<0.05)$, B2 with $\mathrm{B} 3(\mathrm{R}=0.834$; $\mathrm{p}<0.01)$, B4 with B5 $(\mathrm{R}=0.725 ; \mathrm{p}<0.01)$, and B4 with B6 $(\mathrm{R}=0.772 ; \mathrm{p}<0.01) \quad($ Table 2$)$, whereas significant

Table 1. Geographical locations, maximum depths $\left(\mathrm{Z}_{\max }\right)$, and reflectance properties (B1, B2, B3, B4, B5, and B6) for studied lakes.

\begin{tabular}{|c|c|c|c|c|c|c|c|c|c|c|}
\hline \multicolumn{11}{|c|}{ Bulgarian lakes $[1,2]$} \\
\hline & $\begin{array}{c}\text { Geographical } \\
\text { location }\end{array}$ & $\begin{array}{l}Z_{\max } \\
(\mathrm{m})\end{array}$ & $\begin{array}{l}\text { Altitude } \\
\text { (m a.s.1.) }\end{array}$ & $\begin{array}{l}\text { Surface } \\
\left(\mathrm{km}^{2}\right)\end{array}$ & B1 & $\mathrm{B} 2$ & B3 & B4 & B5 & B6 \\
\hline Alekovo & $42^{\circ} 11^{\prime} \mathrm{N} ; 23^{\circ} 34^{\prime} \mathrm{E}$ & 14.5 & 1545 & 0.24 & 0.009137 & 0.009684 & 0.006862 & 0.017300 & 0.018221 & 0.017228 \\
\hline Babreka & $42^{\circ} 12^{\prime} \mathrm{N} ; 23^{\circ} 18^{\prime} \mathrm{E}$ & 28.0 & 2282 & 0.85 & 0.006970 & 0.004789 & 0.004609 & 0.020719 & 0.015184 & 0.008616 \\
\hline Bliznaka & $42^{\circ} 12^{\prime} \mathrm{N} ; 23^{\circ} 18^{\prime} \mathrm{E}$ & 27.5 & 1143 & 0.91 & 0.006970 & 0.006984 & 0.006862 & 0.024139 & 0.012147 & 0.008616 \\
\hline Dolnoto & $42^{\circ} 09^{\prime} \mathrm{N} ; 23^{\circ} 35^{\prime} \mathrm{E}$ & 5.5 & 2368 & 0.11 & 0.006970 & 0.007236 & 0.002355 & 0.020719 & 0.015184 & 0.005745 \\
\hline $\begin{array}{c}\text { Gorno } \\
\text { Marichino }\end{array}$ & $42^{\circ} 09^{\prime} \mathrm{N} ; 23^{\circ} 35^{\prime} \mathrm{E}$ & 10.8 & 2378 & 2.15 & 0.004803 & 0.012131 & 0.009116 & 0.027558 & 0.024294 & 0.011487 \\
\hline Karakashevo & $42^{\circ} 10^{\prime} \mathrm{N} ; 23^{\circ} 35^{\prime} \mathrm{E}$ & 6.6 & 2391 & 0.26 & 0.006970 & 0.009684 & 0.009116 & 0.024139 & 0.024294 & 0.020099 \\
\hline Okoto & $42^{\circ} 11^{\prime} \mathrm{N} ; 23^{\circ} 18^{\prime} \mathrm{E}$ & 37.5 & 2440 & 0.68 & 0.006970 & 0.012131 & 0.009116 & 0.030978 & 0.015184 & 0.011487 \\
\hline Ribnoto & $42^{\circ} 11^{\prime} \mathrm{N} ; 23^{\circ} 18^{\prime} \mathrm{E}$ & 6.5 & 2184 & 0.35 & 0.013472 & 0.019473 & 0.011369 & 0.027558 & 0.021257 & 0.008616 \\
\hline Salzata & $42^{\circ} 11^{\prime} \mathrm{N} ; 23^{\circ} 18^{\prime} \mathrm{E}$ & 4.5 & 2535 & 0.07 & 0.006970 & 0.017025 & 0.009116 & 0.034397 & 0.030368 & 0.017228 \\
\hline Trilistnika & $42^{\circ} 11^{\prime} \mathrm{N} ; 23^{\circ} 18^{\prime} \mathrm{E}$ & 6.5 & 2216 & 0.02 & 0.009137 & 0.014578 & 0.011369 & 0.027558 & 0.021257 & 0.008616 \\
\hline \multicolumn{11}{|c|}{ Chilean lakes } \\
\hline & $\begin{array}{c}\text { Geographical } \\
\text { location }\end{array}$ & $\begin{array}{l}Z_{\max } \\
(\mathrm{m})\end{array}$ & $\begin{array}{l}\text { Altitude } \\
\text { (m) }\end{array}$ & $\begin{array}{c}\text { Surface } \\
\left(\mathrm{km}^{2}\right)\end{array}$ & B1 & B2 & B3 & B4 & B5 & B6 \\
\hline Tinquilco & $39^{\circ} 10^{\prime} \mathrm{S}, 71^{\circ} 43^{\prime} \mathrm{W}$ & 40.0 & 840 & 10.00 & 0.022201 & 0.016090 & 0.012502 & 0.007827 & 0.016396 & 0.003627 \\
\hline Toro & $39^{\circ} 08^{\prime} \mathrm{S} ; 71^{\circ} 42^{\prime} \mathrm{W}$ & No data & 1254 & No data & 0.015221 & 0.011170 & 0.007998 & 0.004145 & 0.012137 & 0.002053 \\
\hline Verde & $39^{\circ} 08^{\prime} \mathrm{S} ; 71^{\circ} 42^{\prime} \mathrm{W}$ & No data & 1240 & No data & 0.017063 & 0.012925 & 0.010691 & 0.004520 & 0.011340 & 0.002315 \\
\hline Chaiquenes & $41^{\circ} 34^{\prime} \mathrm{S} ; 72^{\circ} 32^{\prime} \mathrm{W}$ & No data & 538 & 0.58 & 0.021168 & 0.015590 & 0.011889 & 0.006522 & 0.013080 & 0.005444 \\
\hline Sargazo & $41^{\circ} 30^{\prime} \mathrm{S} ; 72^{\circ} 36^{\prime} \mathrm{W}$ & No data & 354 & 1.40 & 0.019510 & 0.014122 & 0.010763 & 0.005157 & 0.010244 & 0.003287 \\
\hline Triángulo & $41^{\circ} 36^{\prime} \mathrm{S} ; 72^{\circ} 38^{\prime} \mathrm{W}$ & No data & 285 & 0.58 & 0.017038 & 0.012317 & 0.009000 & 0.004328 & 0.009226 & 0.003333 \\
\hline
\end{tabular}


Table 2. Correlation matrix for variables considered in the present study (values in bold denote significant correlation; $p<0.05$ ).

\begin{tabular}{|c|c|c|c|c|c|}
\hline & B1 & B2 & B3 & B4 & B5 \\
\hline B6 & $\mathbf{- 0 . 6 8 8}$ & -0.102 & -0.158 & $\mathbf{0 . 7 2 5}$ & $\mathbf{0 . 7 7 2}$ \\
\hline B5 & $\mathbf{- 0 . 5 4 7}$ & 0.292 & 0.085 & $\mathbf{0 . 7 6 2}$ & \\
\hline B4 & $\mathbf{- 0 . 8 3 4}$ & -0.015 & -0.207 & & \\
\hline B3 & $\mathbf{- 0 . 6 0 7}$ & 0.834 & & & \\
\hline B2 & $\mathbf{0 . 4 9 9}$ & & & & \\
\hline
\end{tabular}

Table 3. PCA contribution percentages of variables for axis 1 and axis 2 .

\begin{tabular}{|c|c|c|}
\hline & 1 & 2 \\
\hline B1 & 0.520 & -0.157 \\
\hline B2 & 0.178 & -0.637 \\
\hline B3 & 0.261 & -0.576 \\
\hline B4 & -0.492 & -0.182 \\
\hline B5 & -0.409 & -0.415 \\
\hline B6 & -0.470 & -0.182 \\
\hline
\end{tabular}

inverse correlations were found between $\mathrm{B} 1$ with $\mathrm{B} 3$ $(\mathrm{R}=-0.607 ; \mathrm{p}<0.05), \mathrm{B} 1$ with $\mathrm{B} 4(\mathrm{R}=0.834 ; \mathrm{p}<0.01)$, $\mathrm{B} 1$ with $\mathrm{B} 5(\mathrm{R}=0.547 ; \mathrm{p}<0.05)$, and $\mathrm{B} 1$ with $\mathrm{B} 6$ $(\mathrm{R}=-0.688 ; \mathrm{p}<0.05)$ (Table 2$)$. PCA revealed that the main contributor variables for axis 1 were $\mathrm{B} 1, \mathrm{~B} 4, \mathrm{~B} 5$, and $\mathrm{B} 6$, whereas for the second axis the main variables where B2 and B3 (Table 3, Fig. 1). The PCA revealed that sites Alekovo, Babreka, Bliznaka, and Dolnoto have low B1, $\mathrm{B} 2$, and $\mathrm{B} 3$ reflectance values, and high $\mathrm{B} 4, \mathrm{~B} 5$, and $\mathrm{B} 6$ reflectance values (Fig. 1), whereas Toro, Triangulo, and Verde have high B1, B2, and B3 reflectance values, and

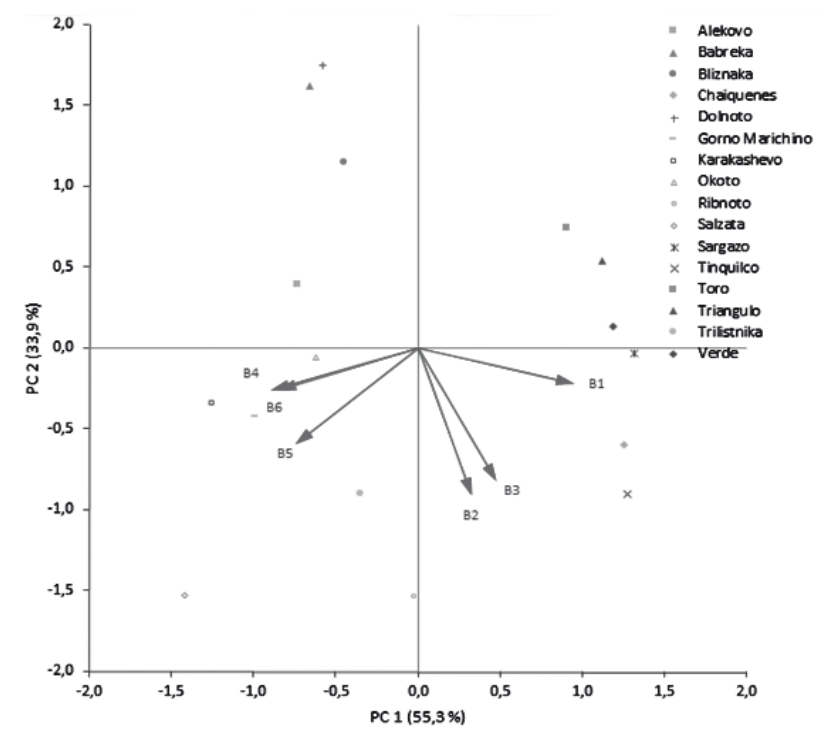

Fig 1. PCA analysis for variables considered in the present study. low B4, B5, and B6 reflectance values (Fig. 1), whereas for Sargazo, Verde, and Chaiquenes we found B1, B2, and B3 high values, and B4, B5, and B6 low values (Fig. 1). Finally for Okoto, Karaschevo, Trilistnika, Ribnoto, Salzata, and Gorno Marichino we found high B4, B5, and $\mathrm{B} 6$ reflectance values, and low $\mathrm{B} 1, \mathrm{~B} 2$, and $\mathrm{B} 3$ reflectance values (Fig. 1).

\section{Discussion}

The present study revealed differences in optical properties for Bulgarian and Chilean lakes. Both groups were markedly different probably due to geological and associated vegetation [1-2, 4]. Nevertheless, the marked differences for Bulgarian lakes would agree with the marked heterogeneity of the environments of these sites [1-2], which would be denoted using remote sensing techniques such as those observed for Patagonian lakes with marked environmental heterogeneity like that observed for Tagua Tagua and General Carrera lakes [6-8].

The environmental heterogeneity for Patagonian lakes has been described with details mainly of trophic status and associated basins [9-11], but recently we studied some optical properties associated with ecological implications due to the presence of associated glaciers with consequent changes in water coloration properties, light absorption, and changes in associated trophic webs [12-14], and these results would be associated with optical properties obtained from satellite images [6-8]. This scenario would have seen similar results if it had applied similar techniques for Bulgarian lakes that are characterized by their marked environmental heterogeneity, because these lakes have a mixture of volcanic and glacial origins and surrounding vegetation with Pinus mugus shrubs, associated with mountains and Fagus forests [1-2]. This scenario would probably have potential correlations between optical, chemical, and trophic status with consequent responses on plankton communities [15].

The presented results indicate that a potential correlation between environmental associations due to surrounding basins and optical properties might possibly be found. However, it would be necessary to carry out more intensive studies and obtain more data to confirm or discount the possibility of finding potential correlations and their variations in multiple spatial and temporal scales [16].

\section{Acknowledgements}

Our thanks for financial support from the TIDES TRF13-03011 and MECESUP UCT 0804 projects, and to M.I for her valuable comments and suggestions.

\section{References}

1. HRISTOZOVAM., BOTEV I., KALCHEV R., NAIDENOW W. Composition and temporal changes of zooplankton in 
high mountains lakes in the Rila mountains (South-West Bulgaria). Acta Zoologica Bulgarica, 56, 341, 2004.

2. KALCHEV R., BOTEV I., HRISTOZOVA M., NAIDENOW W., RAIKOVA-PETROVA G., STOYNEVA G., TEMMNISKOVA-TOPALOVA D. TRICHKOVA T. 2004. Ecological relations and temporal changes in the pelagial of the high mountain lakes in the Rila mountains (Bulgaria). Journal of Limnology, 63, 90, 2004.

3. HAUENSTEIN E., BARRIGA K., DE LOS RÍOSESCALANTE P. Macrophytes assemblages in mountain lakes of Huerquehue National Park ( $39^{\circ} \mathrm{S}$, Araucanía Region, Chile). Latin American Journal of Aquatic Research, 39, 593, 2011.

4. DE LOS RÍOS-ESCALANTE P., HAUENSTEIN E., ACEVEDO P., ROMERO-MIERES M., PANDOURSKI I. Regulatory factors in crustacean zooplankton assemblages in mountain lakes of northern Chilean Patagonia $\left(38-41^{\circ} \mathrm{S}\right)$ : a comparison with Bulgarian counterparts. Latin American Journal of Aquatic Research, 40, 473, 2012.

5. DE LOS RÍOS P., HAUENSTEIN E., ACEVEDO P., JAQUE $X$. Littoral crustaceans in mountain lakes of Huerquehue National Park ( $38^{\circ} \mathrm{S}$, Araucania region, Chile). Crustaceana, 80, 401, 2007.

6. DE LOS RÍOS-ESCALANTE P., ACEVEDO P. First observations on zooplankton and optical properties in a glacial north Patagonian lake (Tagua Tagua lake, $41^{\circ} \mathrm{S}$ Chile). Polish Journal of Environmental Studies, 25, 453, 2016.

7. DE LOS RÍOS-ESCALANTE P., ACEVEDO P. First observations of Boeckella michaelseni Mrázek 1901 (Crustacea, Copepoda) and optical properties of central Patagonian lake (General Carrera Lake, $46^{\circ} \mathrm{S}$ Chile). Polish Journal of Environmental Studies, In press.

8. DE LOS RÍOS-ESCALANTE P., QUINAN E., ACEVEDO P. Crustacean zooplankton communities in lake General Carrera $\left(46^{\circ} \mathrm{S}\right)$ and their possible association with optical properties. Crustaceana, 86, 507, 2013.
9. MODENUTTI B.E., BALSEIRO E.G., QUEIMALIÑOS C.P., SUAREZ D.A., DIÉGUEZ M.C., ALBARIÑO R.J. Structure and dynamics of food webs in Andean lakes. Lakes and Reservoirs, Research and Management, 3, 179, 1998.

10. SOTO D. Oligotrophic patters in southern Chilean lakes: the relevante of nutrients and mixing depth. Revists Chilena de Historia Natural, 75, 393, 2002.

11. KROGH S.A., POMEROY J.W., McPHEE J., Physically based mountain hydrological modeling using reanalysis data in Patagonia. Journal of Hydrometeorology, 16, 172, 2015.

12. PASQUINI A.I., DEPETRIS P.J., Southern Patagonia's Perito Moreno Glacier, Lake Argentino and Santa Cruz river hydrological system: an overview. Journal of Hydrology, 405, 48, 2011.

13. LASPOUMADERES C., MODENUTTI B., SOUZA M., BASTIDAS M., CUASSOLO F., BALSEIRO E., 2013. Glacier melting and stoichiometric implications for lake community structure: zooplankton species distributions across a natural light gradient. Global Change Biology, 19, 316, 2013.

14. HYLANDER S., JEPHSON T., LEBRET, K., VON EINEM J., FAGEBERG T., BALSEIRO E., MODENUTTI B., SOUZA M., LASPOUMADERES, C., JÖHNSON M., LJUNGBERG P., NICOLLE A., NILSSON P.A., RANAKER L., HANSSON L.A. Climate-induced imput of turbid glacial meltwater affects vertical distribution and community composition of phyto- and zooplankton. Journal of Plankton Research, 33, 1239, 2011.

15. PALMER S.C.J., HUNTER P.D., LANKESTER T., HUBBARD S., SPYRAKOS E., TYLER A.N., PRÉSIG M., HORVATH H., LAMB, A., BALSTER H., TOTH V.R., Validation of envisat MERIS algorithms for chlorophyll retrievan in a large turbid and optically-complex shallow lake. Remote Sensing of Environment 157, 158, 2015.

16. PALMER S.C.J., KUTZER T., HUNTER P.D. Remote sensing of inland waters: challenges, progress and future directions. Remote sensing of Environment, 157, 1, 2015. 